\begin{tabular}{lr}
\hline \multicolumn{1}{c}{ D Y N A M I C E C O N O M E T R I C } & M O D E L S \\
DOI: http://dx.doi.org/10.12775/DEM.2019.003 & Vol. 19 (2019) 41-56 \\
\hline $\begin{array}{l}\text { Submitted July 3, 2019 } \\
\text { Accepted December 20, 2019 }\end{array}$ & ISSN (online) 2450-7067 \\
ISSN (print) 1234-3862
\end{tabular}

Sebastian A. Royø*

\title{
Demonetisation as an Economic Policy Tool: Macroeconomic Implications of a Monetary Market Shock. The Example of the Indian Monetary Reform
}

\begin{abstract}
A b s tra ct. This paper discusses the implementation of the 2016 India demonetisation, and analyses its macroeconomic consequences. The pivotal issue here is a regional heterogeneity of CPI inflation caused by demonetisation. A dynamic panel CPI model has been estimated in order to find out whether unequal accessibility of banking services determines the inflation heterogeneity. The findings suggest that financial services accessibility is not a significant inflation-driving factor. Hence a hypothesis about a redistribution of wealth between rural and urban areas with different access to banking might be rejected.
\end{abstract}

K e y w ord s: developing economies; inflation; macroeconomic policy; monetary policy; panel econometrics.

J E L Classification: E02, E26, E31, E52; C01, C23

\section{Introduction}

Demonetisation in India was announced on 8 November 2016 and included pulling from circulation banknotes of the two highest denominations (500 INR and 1,000 INR). Subsequently, new series of 500 INR and 2,000 INR notes were issued, but in order to exchange the old notes it was required to make a bank account deposit (Killawala, 2016b). According to OECD, the

\footnotetext{
* Correspondence to: Sebastian A. Roy, SGH Warsaw School of Economics, Kazimierza Promyka 5/80, 01-604 Warszawa, e-mail: sebastian.amit.roy@gmail.com

(C) 2019 Nicolaus Copernicus University. All rights reserved. http://www.dem.umk.pl/dem
} 
demonetised notes composed $86 \%$ of cash in circulation (Beyes and Bhattacharya, 2017).

The demonetisation was designed to achieve four goals: curbing black economy, tackling bribery, targeting counterfeit notes, and cutting resources of terrorist organisations (Modi, 2017). Such a selection of aims implies that the demonetisation needs to be analysed not only in its economic dimension, but also in a social one.

Whatever its political and institutional motivations, Indian monetary reform remains a macroeconomic experiment of substantial interest, perhaps the most sweeping change in currency policy that has occurred anywhere in the world in decades, according to the former US treasury secretary Lawrence Summers (Sharma, 2016). It is worth noting that experiment is scarcely used in macroeconomic research - this is due to the fact that hardly would anybody allow economists to wreak havoc in lives of millions for sake of their curiosity (Czarny, 2017). Moreover, the demonetisation may be considered as a ceteris paribus negative shock in the M1 money supply, since it was introduced in times of solid economic growth and in a stable political environment. This allows usage of the post-demonetisation macroeconomic data in empirical studies of price flexibility in emerging markets and inflation-driving factors.

Demonetisation has received limited interest from the researchers. First analyses, most of them penned by economic journalists, were published in December 2016 by media such as The Economist (2016), Forbes (Worstall, 2016), and Al Jazeera (Sharma, 2016). They were followed by a number of speculative papers published by mostly Indian think-tanks and universities. Their common characteristic was, however, lack of empirical evidence for discussed hypotheses - none of them employed formal statistical inference in order to support authors' reasoning, except for the paper by Chodorow-Reich, Gopinath, Mishra et al. (2018). In Polish literature demonetisation has attracted even weaker attention. In December 2016 the issue was examined in Monitoring Makroekonomiczny (Roy, 2016).

This paper aims at discussing implementation of the 2016 Indian demonetisation and its macroeconomic consequences. In the first section it presents a detailed analysis of the reform implementation process, based on the authorities' announcements. The second section aims to analyse possible macroeconomic consequences of driving $86 \%$ of cash out of the circulation. It comprises an empirical study alongside with a broad discussion of the literature. The key hypothesis here is presence of a regional heterogeneity of CPI inflation caused by demonetisation. A dynamic, individual effects CPI model has been estimated in order to find out whether unequal accessibility of banking services determines the inflation heterogeneity. Moreover, the analysis also 
discusses the reform's possible impacts on GDP and the role of elasticities in shaping the real sector response to a nominal shock.

The CPI heterogeneity research is based on a panel dataset of monthly observations for 35 Indian states with distinction between rural and urban areas in the post-demonetisation period. Estimates show that a hypothesis of a positive short-run correlation between banking accessibility and CPI growth rates can be rejected under all circumstances. Hence unequal accessibility of banking services couldn't have driven cross-sectional CPI inflation variability following demonetisation.

\section{Implementation of the Demonetisation}

\subsection{Primary Demonetisation Mechanism}

The earliest source of information about the technical details of the process of withdrawing and exchanging the old notes was an address by the PM Narendra Modi broadcasted on 8 November 2016. More formally, demonetization was scheduled by two Reserve Bank of India (RBI) statements (Vijaya Kumar, 2016a; Dave, 2016). Later some elements of the reform were corrected and adjusted in response to certain difficulties arising. The first demonetization schedule comprised the following points (Modi, 2017):

1. Owners of the old $500 \mathrm{INR}$ and 1,000 INR notes may deposit them at a bank or post office from 10 November to 30 December 2016 with no limitations.

2. Cash withdrawals from bank accounts shall not exceed 10,000 INR per day and 20,000 INR per week. The limit is to be relaxed in a short time.

3. Over-the-counter notes exchange for immediate needs is possible at every bank or post office. Such an exchange is limited to 4,000 INR. After 24 December the limit shall be increased ${ }^{1}$.

4. Any person unable to exchange their old notes before 30 December 2016 may do the exchange at certain RBI branches before 31 March 2017.

5. On 9 December 2016 (in particular cases, on 10 December as well) ATMs shall be shut due to recalibration. After recalibration cash withdrawals are limited to 2,000 INR per card. The limit shall be increased to 4,000 INR in a short time.

6. Cashless transactions via cheques or electronic transfers may be conducted with no restrictions.

\footnotetext{
${ }^{1}$ Eventually the limit was not changed. On 24 November 2016 RBI decided to end the OTC exchanges (Beyes and Bhattacharya, 2017).
} 
7. Due to convenience and humanitarian reasons the following units will accept payments made in the old notes within 72 hours from the announcement of the demonetization:

a. Public hospitals and drug stores located therein (only for medicines prescribed by a physician)

b. Bus, train and flight ticket booking points

c. Petrol stations authorised by the national oil companies

d. Consumer cooperative stores authorized by the state or central government

e. Milk booths authorized by the state authorities

f. Burial grounds and crematoria

g. Currency exchange offices at international airports

The vital part of the demonetisation policy, designed to tackle bribery and black economy, was obligatory fiscal investigation of every newly created bank deposit of 250,000 INR or more (Roy, 2016). Failure in proving that the due tax had been payed could end up with being fined $200 \%$ of the overdue fiscal liabilities (Rowlatt, 2016).

\subsection{Modifications of the Demonetisation Mechanism}

The primary organization of the reform was subject to multiple alterations after 8 November 2016. Due to a significant number of modifications OECD experts Peter Beyes and Reema Bhattacharya described Indian demonetisation as evolutionary (Beyes and Bhattacharya, 2017). According to their research, in the central period of the reform (that is from 8 November to 30 December 2016) RBI issued 50 announcements concerning demonetisation, majority of whose significantly modified its implementation. On the other hand, Ministry of Finance issued 19 such announcements, part of which actually mirrored those produced by the RBI.

The most important modifications of the reform concerned means of depositing and exchanging old notes as well as limits of cash withdrawals. Those were issues of outstanding significance for the rural areas inhabitants. Cash shortages posed a serious threat to farmers who could not pay for seeds for winter sowing.

On 14 November 2016 RBI decided to withdraw the right to exchange ${ }^{2}$ notes from two most popular rural financial institutions, District Central Cooperative Bank (DCCB) and Primary Agricultural Credit Society (PACS) (Vijaya Kumar, 2016c). RBI decision was founded on a suspicion that DCCB and

\footnotetext{
${ }^{2}$ Those institutions were no more allowed to deposit old notes.
} 
PACS were used for money laundering, as between 8 and 14 November 2016 they noted outstandingly high inflow of cash (Beyes and Bhattacharya, 2017). As a result, accessibility to the banking services was seriously restrained in the rural areas, whose inhabitants had to commute to towns or cities in order to exchange their notes.

Demonetisation timing further exacerbated circumstances for the agricultural sector. In November Indian farmers harvest their summer crops and sow winter seeds. Free access to financial services is of utmost importance as it allows for depositing resources obtained from summer crops sales and provides funding for sowing seeds. Therefore, RBI decision concerning DCCB and PACS met strong resistance. In response to the social distress, on 20 November 2016 farmers were allowed to purchase seed with old banknotes (Dhoot, 2016). Moreover, on 21 November RBI raised the cash withdrawal limit to 25,000 INR for farmers (Vijaya Kumar, 2016b).

\section{Macroeconomic Consequences of the Reform}

\subsection{Literature Review}

The literature discussing demonetisation in India comprises two groups of articles. First set contains articles published in various economic magazines shortly after the reform had been announced. Among them three deserve special interest. The first, authored by White and Rajagopalan (2016) from Foundation for Economic Education (FEE), discusses selected issues of remonetisation, including seigniorage; second, by Forbes' Worstall (2016), provides one of the earliest discussions of the impact demonetisation might have on GDP growth; the third, by The Economist (2016), analyses social impact of the reform. The second set comprises research papers covering multivariate issues of the demonetisation.

In a Keynesian-inspired paper Impact of Demonetisation on India: a Macro-theoretic Analysis A. Ghosh (2017) develops a disaggregated demand model with two sectors: organised and unorganised. The unorganised sector uses organised sector output as the only input and produces goods that have perfectly flexible prices. Due to illiteracy and restricted access to collateral, the unorganised sector settles all transactions in cash, hence it must posess certain cash holdings. On the other hand, the organised sector is an oligopoly that uses two inputs: capital and labour. There are markups on wages and capital rental rates, with short-run wages constant. The organised sector may be considered cashless except for transactions with the unorganised sector. 
Ghosh uses his model to determine possible impact of demonetisation on the Indian economic growth, but his findings are ambiguous. Cash supply slump may lower production of the unorganised sector, which in turn should make the organised sector output decrease - all in all, total production shall fall. On the other hand, lower cash supply could increase demand for the goods produced in the organised sector, thus boosting GDP. However, Ghosh argues that such a demand shift shall be limited due to low accessibility of the organised sector output in less affluent areas and reluctance towards cashless payments.

One of the earliest macroeconomic papers on the monetary reform is the one by the National Institute of Public Finance and Policy (NIPFP) from 14 November 2016 (Rao, Mukherjee, Kumar et al., 2016). It provides an analysis of short- and medium-run effects of the negative money supply shock based on four types of transaction demand for cash. Those include accounted transactions, unaccounted transactions, informal sector transactions, and illegal transactions. Furthermore, it includes credit supply and public finance issues.

In the short-run the report predicts a sharp fall in households' income and consumption due to a plunge in money supply. Similarly, to Ghosh (2017), the NIPFP experts suggest that the informal sector might be affected stronger than the formal one. Interestingly, they oppose a common notion that the reform will induce CPI deflation. Contrarily - if cash shortage makes firms produce less, prices may even rise. Finally, demand of those who do not have access to digital payment methods shall decrease, thus lowering the aggregate demand.

In the medium-run Rao, Mukherjee, Kumar, et al. stress that impact of the reform will depend on the remonetisation scale. If the authorities manage to conduct remonetisation swiftly ${ }^{3}$, effects should be mild and scarce. However, there are several sectors with high probability of being affected, including agriculture and construction. The report notes also a possible positive effect that growing deposits may have on the credit supply and, eventually, on the whole economy.

Das and Rawat (2017) from Institute for Studies in Industrial Development (ISID) evaluate demonetisation's performance against its intended targets alongside discussing it from a GDP growth perspective. Their conclusions are pessimistic. They find that the reform's efficiency in fighting black economy and counterfeit currency is too low to outweigh macroeconomic threats it

\footnotetext{
${ }^{3}$ That is, if remonetisation does not exceed two months (Rao, Mukherjee, Kumar et al., 2016).
}

Dynamic Econometric Models 19 (2019) 41-56 
poses. Moreover, they interpret early post-demonetisation macroeconomic indicators as disappointing.

Siddiqui, Mishra and Tiwari (2017) present an analysis including fiscal consequences of the demonetisation. They suggest that allowing for paying taxes in demonetised notes might be a strong incentive for quicker and more comprehensive filling for tax return. After examining Ministry of Finance fiscal data, they argue that the fiscal authorities noted a $260 \%$ rise in municipal and local tax payments within 14 days from demonetisation.

\subsection{Regional Heterogeneity of Inflation. Price Arbitrage Hypothesis}

Interestingly, issue of post-demonetisation regional diversity of prices is not discussed in the literature except for the paper by White and Rajagopalan (2016). Arguably, unequal access to financial services could contribute to cross-sectional deflation heterogeneity.

In the process of exchanging old notes commercial banks played a crucial role. This could lead to regional differentiation in remonetisation dynamics, conditional on local accessibility to financial services. Arguably, M1 money supply in the rural areas with poorer access to banks might have been lower than in urban localities, where financial institutions were better accessible, particularly given restrictions on DCCB and PACS (Vijaya Kumar, 2016c).

According to the Keynesian aggregated demand framework, prices are sticky in the short-run (Czarny, 2017). This assumption has a robust justification; indeed, there is a wide consensus among economists that flexible price assumptions of the quantity theory of money are not satisfied but in a longrun analysis (Sławiński, 2011). However, Indian economy is heavily cash-dependent as $90 \%$ of all transactions there are settled in cash (Beyes and Bhattacharya, 2017). Hence in the Indian case of an abrupt demonetisation of $86 \%$ of cash in circulation prices can be flexible even in the short-run. It is worth noting that Ghosh (2017) reaches a similar conclusion while specifying his macro-theoretic model. Summing up, it is justified to expect that in the areas with high banking accessibility slump in the M1 money supply was milder, thus dampening change of prices. Specifically, CPI deflation could be deeper in poorer states, but also there could occur within-state price index heterogeneity between rural and urban areas.

Unlike international price differentiation, neither within- nor betweenstate CPI heterogeneities could not be neutralized through the exchange rate as INR is a legal tender in the whole Indian territory. Hence temporary or persistent purchasing power diversity could be employed in a following arbitrage scheme: 
1. Capital transfer to the locality with higher purchasing power (equivalently, with deeper deflation)

2. Purchase of goods at lower prices

3. Shipping the goods back to the area with lower purchasing power (equivalently, with milder deflation)

4. Selling the goods with profit

Arbitrage results with a wealth transfer from regions suffering from deeper deflation to those with higher prices. Since CPI dynamics depends on financial services accessibility, which is higher in more affluent, often urbanised regions, post-demonetisation arbitrage could lead to deepening economic inequalities in India. This effect could be further amplified by the fact that business entities from the wealthy regions were able to take advantage of their well-developed distribution networks.

Nonetheless; conducting such an arbitrage scheme would pose multiple difficulties, e.g. in specifying goods whose prices differ regionally. Tackling it in detail would require scrutinizing trade flows in India, which falls beyond scope of this paper. Therefore the empirical study presented in the final chapter discusses regional price heterogeneity only, leaving aside question of whether arbitrage actually took place.

\subsection{Real Economy Response to the Money Supply Shock. Nominal Rigidities and Shift of the Long-run AS Curve (LAS)}

Demonetisation impact on the GDP has been widely discussed since the very first days of the reform, with the earliest paper tackling this issue being that of Rao, Mukherjee, Kumar et al. (2016) published five days from the reform commencement. While there is a broad consensus that in the short run consumption (and consequently aggregated demand) shrank, opinions about demonetisation's long-run impact on the real economy vary significantly. This chapter studies long-run response of the real sector to the money supply shock, paying particular attention to the possibility of a long-run AS curve shift caused by a substantial shrink in the money supply. 


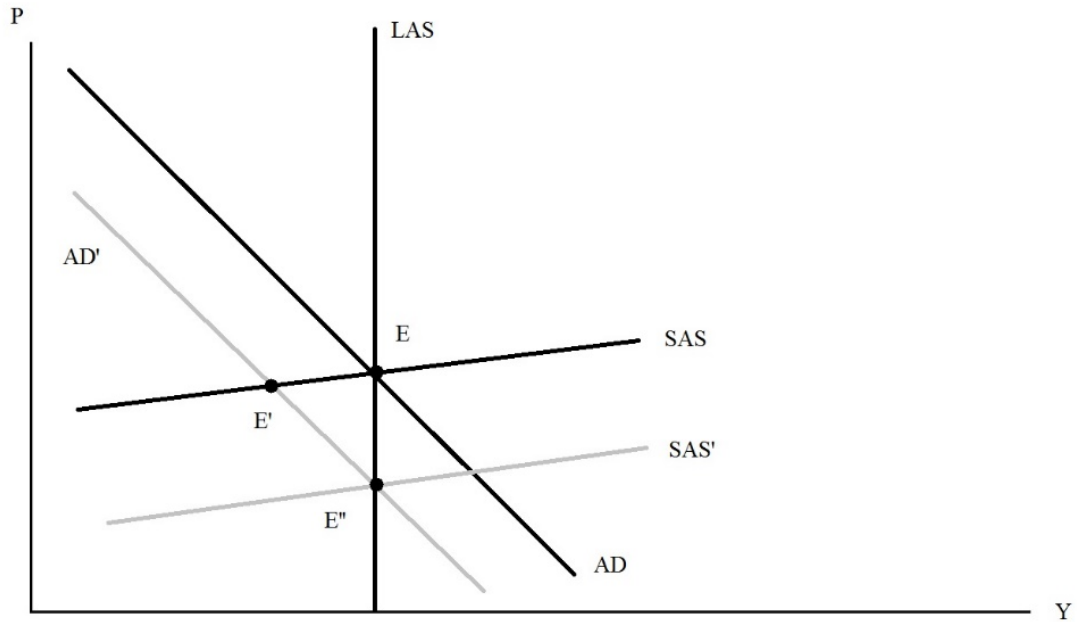

Figure 1. AD-AS model

Real economy analysis will be founded on the AD-AS framework (compare Czarny, 2017). In AD-AS model economy reaches equilibrium at the intersection of negative aggregated demand (AD) curve, flat and positive shortrun aggregated supply (SAS) curve and vertical long-run aggregated supply (SAS) curve. In the Fig. 1 equilibrium is denoted as E. Under AD-AS approach a money supply slump is a negative demand shock, which shifts the demand from $\mathrm{AD}$ to $\mathrm{AD}$ '. Hence temporary equilibrium is reached at the point E', where AD' and SAS intersect. The temporary equilibrium is characterized with slightly lower prices and substantially decreased output. In the long run, however, SAS curve shifts downward and a new equilibrium E" is reached with the pre-shock level of output, but lower prices. This illustrates that in the long run money the real sector is independent from nominal shocks.

The AD-AS analysis above could be summarized in a following way: a demonetisation-caused negative demand shock in the short run lowers the output due to nominal rigidities. After certain adjustments, the economy reaches new equilibrium with potential output and lower prices. That means that in the long run a negative demand shock affects the nominal economy only.

There are two assumptions in the AD-AS approach that deserve special scrutiny. The first is: were prices in India actually sticky in the post-demonetisation period? Price stickiness is a crucial assumption for the AD-AS analy- 
sis. There is massive literature covering the nominal rigidity issue, both theoretical, such as Burda and Wyplosz (2012), Begg, Fischer, Vernasca et al. (2014), Czarny (2017), and empirical, e.g. Banerjee and Bhattacharya (2017), Chong, Zhu and Rafiq (2013); it is also in line with assumptions of the benchmark demonetisation research made by Chodorow-Reich, Gopinath, Mishra et al. (2018). However, is it justified to assume that after such a dramatic demand shock as demonetisation of $86 \%$ of cash in circulation, prices remained sticky?

On the one hand, it is reasonable to suspect that about 7 times higher decrease of cash supply in an economy with approx. $100 \%$ of all transactions volume and $70 \%$ of their value settled in cash should cause a fall in CPI. On the other hand, remonetisation started immediately after the reform was announced, which could limit its effect on inflation.

Price stickiness assumption may be verified empirically with a time series analysis. Figure 2 shows the Reserve Bank of India (RBI) data about year-onyear CPI inflation and year-on-year M1 money growth rate. According to the data there is no ground for rejection of the short-run price stickiness hypothesis. Within two quarters from the beginning of the reform there occurred a slight CPI deflation; nevertheless, negative price dynamics not exceeding 5 percentage points do not differ significantly from its pre-demonetisation levels.

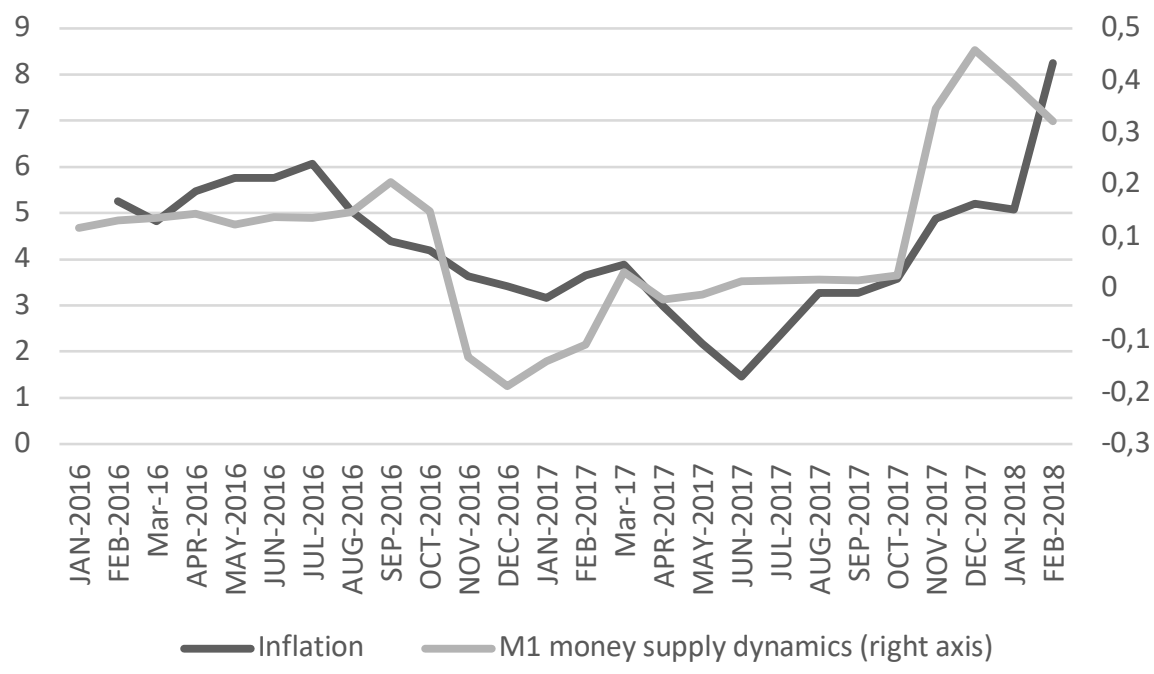

Figure 2. Inflation and M1 money supply dynamics 
The second AD-AS model assumption that needs to be re-considered, is constant potential output or, in other words, issue whether LAS curve is fixed. Standard justification for this assumption says that the potential output depends solely supply-driven, depending only on technology and means of production.

Constant potential output assumption may be true only if hardships caused by demonetisation did not result with substantial number of insolvencies between Indian business entities. Among them small enterprises which generally settle in cash and have limited access to credit ${ }^{4}$, could be affected in a stronger way. Hence long run demonetisation impact on the aggregated supply should depend on general market flexibility. If entrepreneurs failed to display enough perseverance to operate under cash shortages and became insolvent, decrease in potential output should be expected. Such a wave of insolvencies would directly result with persistent decrease of different types of capital: physical (machines in the case of craftsmen, vehicles in the case of rickshaw drivers), human (know-how) and institutional (cutting employer-employee relations).

There is empirical, macroeconomic evidence that in the months following demonetisation the number of bankruptcies among small entrepreneurs actually rose (Shirley, 2017). RBI negatively corrected the MPC ${ }^{5}$ forecasts of GDP growth for the 2016-17 accounting year. They were adjusted from $7.6 \%$ on 4 October 2016 (Killawala, 2016a) to 6.9\% on 8 February 2017 (Killawala, 2017). Multiple international organisations lowered their forecasts as well.

The data presented below imply that the demonetisation impact on the GDP growth was only temporary, which supports the thesis that there was no shift of the LAS curve. However, post-demonetisation estimation of the potential product of the Indian economy remains a promising field of research.

Table 1. GDP growth forecasts

\begin{tabular}{cccccc}
\hline Institution & WB & IMF & CMIE & ICRA & Fitch \\
\hline Pre-demonetisation growth forecast [\%] & 7.6 & 7.6 & $7, .5$ & 7.7 & 7.4 \\
Post-demonetisation forecast [\%] & 7.0 & 6.6 & 6.0 & 6.8 & 6.9 \\
Forecast change [p. points] & -0.6 & -1.0 & -1.5 & -0.9 & -0.5 \\
\hline
\end{tabular}

Note: WB - World Bank, IMF - International Monetary Fund, CMIE - Centre for Monitoring of Indian Economy, ICRA - Investment Information and Credit Rating Agency of India Ltd.

\footnotetext{
${ }^{4}$ This is partially justified by Ghosh, who says that producers and workers in the unorganized sector cannot access institutional financial facilities because of illiteracy and lack of collateral (2017).

${ }^{5}$ Monetary Policy Committee of India.
} 


\section{Dynamic Panel CPI Model}

\subsection{Research Hypotheses}

A dynamic panel CPI model has been developed in order to verify hypothesis of regional heterogeneity of inflation driven by unequal access to financial services. Formally, methods of statistical inference have been used to study the following hypotheses:

$\mathrm{H1}$ : banking accessibility is a positive, statistically significant inflation-driving factor

$\mathrm{H} 2$ : banking accessibility has a stronger impact on inflation in rural territories

Estimation was computed in R software using $\mathrm{plm}$ package (Croissant and Millo, 2008).

\subsection{The Data}

The model employs a panel dataset of monthly observations for 35 Indian states with distinction between rural and urban areas in the post-demonetisation period. The data has been downloaded from Database on Indian Economy (DBIE) governed by the RBI and from the Census $2011^{6}$ database. Observations for the state of Telangana have been dropped due to missing demographic data. All the variables are discussed in detail in Table 2.

\subsection{Model Specification. Discussion of the Method.}

Hypotheses presented in 3.1 have been verified with three dynamic panel CPI models with fixed effects, estimated separately for rural, urban and aggregate inflation. Such a specification is able to account for cross-sectional heterogeneity and inflation time-persistence. Detailed specification is given below:

$$
\begin{aligned}
& \inf _{i t}=\beta_{1} \inf _{i, t-1}+\beta_{2} \text { dynM }_{t}+\beta_{3} \text { bankingPC }_{i t}+\mu_{i}+\varepsilon_{i t} \\
& \text { Rinf }_{i t}=\beta_{1} \text { Rinf }_{i, t-1}+\beta_{2} \text { dynM } 1_{t}+\beta_{3} \text { RbankingPC }_{i t}+\mu_{i}+\varepsilon_{i t} \\
& \operatorname{Uinf}_{i t}=\beta_{1} \operatorname{Uinf}_{i, t-1}+\beta_{2} \text { dynM }_{t}+\beta_{3} \text { UbankingPC }_{i t}+\mu_{i}+\varepsilon_{i t}
\end{aligned}
$$

Coefficients have been estimated with Arellano and Bond (1991) estimator.

\footnotetext{
${ }^{6}$ Between 2011 and 2016 no Census survey had been conducted.
} 
Table 2. Dataset description

\begin{tabular}{|c|c|c|c|c|}
\hline Variable & Description & Type & Source & Comments \\
\hline Rinf & $\mathrm{CPI}$ yoy inflation rate at rural areas [\%] & Panel, monthly & $\begin{array}{l}\text { DBIE } \\
\text { RBI }\end{array}$ & \\
\hline Uinf & $\mathrm{CPI}$ yoy inflation rate at urban areas [\%] & Panel, monthly & $\begin{array}{l}\text { DBIE } \\
\text { RBI }\end{array}$ & \\
\hline $\inf$ & $\mathrm{CPI}$ yoy inflation rate [\%] & Panel, monthly & $\begin{array}{c}\text { DBIE } \\
\text { RBI }\end{array}$ & \\
\hline dynM1 & M1 money supply yoy growth rate [\%] & $\begin{array}{l}\text { Time series, } \\
\text { monthly }\end{array}$ & $\begin{array}{l}\text { DBIE } \\
\text { RBI }\end{array}$ & $\begin{array}{l}\text { Own calcula- } \\
\text { tions }\end{array}$ \\
\hline Rbranches & $\begin{array}{l}\text { Number of commercial bank branches at } \\
\text { rural areas }\end{array}$ & Panel, quarterly & $\begin{array}{c}\text { DBIE } \\
\text { RBI }\end{array}$ & \\
\hline Ubranches & $\begin{array}{l}\text { Number of commercial bank branches at } \\
\text { urban areas }\end{array}$ & Panel, quarterly & $\begin{array}{l}\text { DBIE } \\
\text { RBI }\end{array}$ & \\
\hline Mbranches & $\begin{array}{l}\text { Number of commercial bank branches at } \\
\text { metropolitan areas }\end{array}$ & Panel, quarterly & $\begin{array}{l}\text { DBIE } \\
\text { RBI }\end{array}$ & \\
\hline branches & $\begin{array}{c}\text { Total number of commercial bank } \\
\text { branches }\end{array}$ & Panel, quarterly & $\begin{array}{l}\text { DBIE } \\
\text { RBI }\end{array}$ & $\begin{array}{l}\text { Own calcula- } \\
\text { tions }\end{array}$ \\
\hline Rpopulation & Rural population & Cross-section & Census & \\
\hline Upopulation & Urban population & Cross-section & Census & \\
\hline Population & Total population & Cross-section & Census & \\
\hline RbankingPC & $\begin{array}{c}\text { Banking accessibility coefficient at rural ar- } \\
\text { eas }^{7}\end{array}$ & Panel, quarterly & & $\begin{array}{l}\text { Own calcula- } \\
\text { tions }\end{array}$ \\
\hline UbankingPC & $\begin{array}{l}\text { Banking accessibility coefficient at urban } \\
\text { areas }^{8}\end{array}$ & Panel, quarterly & & $\begin{array}{l}\text { Own calcula- } \\
\text { tions }\end{array}$ \\
\hline bankingPC & Total banking accessibility coefficient & Panel, quarterly & & $\begin{array}{l}\text { Own calcula- } \\
\text { tions }\end{array}$ \\
\hline
\end{tabular}

\subsection{Regression Analysis}

Table 3 presents the estimates with selected post-estimation statistics ${ }^{9}$. Due to strong second-order autocorrelation of the residuals, robust variancecovariance matrix is used. All the tests assume standard 5\% significance level.

Each panel is balanced. Aggregate inflation panel is of width $n=35$ and length $\mathrm{T}=12$ with $\mathrm{N}=420$ observations altogether, out of which 338 are used in estimation. Rural inflation panel is of width $n=35$ and length $T=12$ with $\mathrm{N}=420$ observations altogether, out of which 348 are used in estimation. Urban inflation panel is of width $n=35$ and length $T=12$ with $N=420$ observations

\footnotetext{
${ }^{7}$ Coefficient calculated as a fraction of number of bank branches at particular area over its population.

${ }^{8}$ Metropolitan areas will be treated as a subset of urban territories, hence UbankingPC $=$ Ubranches+Mbranches.

${ }_{9}^{P}$-values for statistical tests are given in brackets.
} 
altogether, out of which 340 is used in estimation. Differences in sample sizes are due to the missing values structure.

Table 3. Estimation summary

\begin{tabular}{cccccc}
\hline $\begin{array}{c}\text { Dependent } \\
\text { variable }\end{array}$ & $\boldsymbol{\beta}_{\mathbf{1}}$ & $\boldsymbol{\beta}_{\mathbf{2}}$ & $\boldsymbol{\beta}_{\mathbf{3}}$ & $\begin{array}{c}\text { Wald chi-squared } \\
\text { statistic }\end{array}$ & $\begin{array}{c}\text { Arellano-Bond 2nd order } \\
\text { correlation test }\end{array}$ \\
\hline $\boldsymbol{i n f}$ & $\begin{array}{c}0.86 \\
(0)\end{array}$ & $\begin{array}{c}2.47 \\
(0)\end{array}$ & $\begin{array}{c}39,700 \\
(0.35)\end{array}$ & $416.793(0)$ & $-2.5(0.01)$ \\
\hline $\boldsymbol{R} \boldsymbol{i n f}$ & $\begin{array}{c}0.89 \\
(0)\end{array}$ & $\begin{array}{c}2.72 \\
(0)\end{array}$ & $\begin{array}{c}46,496 \\
(0.58)\end{array}$ & $153.673(0)$ & $-2.55(0.01)$ \\
\hline $\boldsymbol{U} \boldsymbol{i n f}$ & $\begin{array}{c}0.74 \\
(0)\end{array}$ & $\begin{array}{c}3.28 \\
(0)\end{array}$ & $\begin{array}{c}117,360 \\
(0.18)\end{array}$ & $420.943(0)$ & $-1.24(0.22)$ \\
\hline
\end{tabular}

Each model tested with Wald chi-squared statistic is statistically significant. Autoregressive part of each model is also significant. Rural inflation proves to be the most persistent with adjacent coefficient taking value of 0.89 . Money supply dynamics is also a significant, positive factor shaping inflation. Its impact is strongest in the urban areas, where money supply growth by 1 percentage points rises inflation by 3.28 percentage points.

Banking accessibility, however, turns to be uncorrelated with CPI inflation. Its coefficients are statistically insignificant with $p$-values of 0.18 for the urban, 0.58 for the rural and 0.35 for the aggregate panel.

It is noteworthy that the urban panel is the only one in which no autocorrelation null hypothesis in the second-order Arellano-Bond test cannot be rejected. This suggests that standard variance-covariance matrix can be used instead of the robust one. Under standard variance-covariance matrix banking accessibility becomes significant with $p$-value close to zero. However, since robust standard errors account not only for autocorrelation, but also other types of non-spherical variance-covariance matrix, conclusions shall be drawn in accordance to the robust error estimates.

\section{Conclusions}

Empirical study shows that both $\mathrm{H} 1$ and $\mathrm{H} 2$ hypotheses stated in subsection 3.1 can be rejected. Banking accessibility proves not to be a significant inflation-shaping factor; therefore, one cannot say that its impact is stronger in the rural areas. This is a strong argument in support of a thesis that citizens of India did not face difficulties connected to unequal access to the financial institutions.

Lack of correlation between banking accessibility and inflation cannot verify whether restrictions imposed by the RBI on DCCB and PACS did not influence prices significantly. This is so because DCCB and PACS counted

Dynamic Econometric Models 19 (2019) 41-56 
into the overall number of bank branches in India regardless of their ability to exchange notes.

\section{References}

Arellano, M. \& Bond, S. (1991). Some Tests of Specification for Panel Data: Monte Carlo Evidence and an Application to Employment Equations. Review of Economic Studies, 58(2), 277-297.

Banerjee, Sh. \& Bhattacharya, R. (2017). Micro-level Price Setting Behaviour in India: Evidence from Group and Sub-Group Level CPI-IW Data. NIPFP Working Paper Series, 17, New Delhi.

Begg, D., Fisher, S., Vernasca, G. et al. (2014). Makroekonomia. Warszawa: PWN.

Beyes, P., \& Bhattacharya, R. (2017). India's 2016 Demonetisation Drive: A Case Study on Innovation in Anti-corruption Policies, Government Communications and Political Integrity. 2017 OECD Global Anti-Corruption \& Integrity Forum.

Burda, M. \& Wyplosz, C. (2012). Makroekonomia. Podręcznik europejski. Oxford University Press.

Chodorow-Reich, G., Gopinath, G., Mishra, P. et al. (2018). Cash and the Economy: Evidence from India's Demonetisation. NBER, 25370

Chong, T. T. L., Zhu, T., Rafiq, M.S. (2013) Are Prices Sticky in Large Developing Economies? An Empirical Comparison of China and India. MPRA Paper, 60985.

Croissant, Y. \& Millo, G. (2008). Panel Data Econometrics in R: The plm Package. Journal of Statistical Software, 27(2), 1-43

Czarny, B. (2017). Podstawy ekonomii. Warszawa: Oficyna Wydawnicza SGH.

Das, S. K. \& Rawat, P. S. (2017). Demonetisation: Macroeconomic Implications for Indian Economy. Institute for Studies in Industrial Development, Working Paper, 197 New Delhi.

Dave, N. S. (2016). Closure of ATM Operations Notification. RBI Notifications (RBI/201617/111). https://www.rbi.org.in/Scripts/NotificationUser.aspx?Id=10683\&Mode=0

Dhoot, V. (2016). Farmers can Purchase Seeds with Banned Rs. 500 Notes. The Hindu, November 21

Ghosh, A. (2017). Impact of Demonetization on India: A Macro-theoretic Analysis. Trade and Development Review, 9(1-2), 57-73.

Killawala, A. (2016a). Fourth Bi-monthly Monetary Policy Statement, 2016-17 Resolution of the Monetary Policy Committee (MPC), Reserve Bank of India. RBI Press Releases.

Killawala, A. (2016b). RBI Press Release 2016-2017/1142. https://rbi.org.in/Scripts/BS_PressReleaseDisplay.aspx?prid=38520

Killawala, A. (2016b). RBI Press Release 2016-2017/1142. https://rbi.org.in/Scripts/BS_PressReleaseDisplay.aspx?prid=38520

Killawala, A. (2017). Sixth Bi-monthly Monetary Policy Statement, 2016-17 Resolution of the Monetary Policy Committee (MPC), Reserve Bank of India. RBI Press Releases.

Modi, N. (2017). PM Modi's 2016 Demonetisation Speech that Shocked India. Business Standard, 8.

Rao, K., Mukherjee, S., Kumar, S. et al. (2016). Demonetisation: Impact on the Economy. New Delhi: NIPFP Working Paper Series, 182.

Rowlatt, J. (2016). Why India Wiped Out $86 \%$ of its Cash Overnight. BBC News, November 14.

Dynamic Econometric Models 19 (2019) 41-56 
Roy, S. A. (2016). Czy 14\% tygrysa to wciąż tygrys? Reforma demonetyzacyjna w Indiach. Monitoring Makroekonomiczny.

Sharma, V. (2016, 12 6). India's Demonetisation: 'Modi Didn't Think of the Poor'. Al Jazeera. https://www.aljazeera.com/indepth/features/2016/11/india-demonetisation-modi-didnpoor-161123073645259.html

Shirley, M. A. (2017). Impact of Demonetization in India. International Journal of Trend in Research and Development, Special Issue, 20-23. http://www.ijtrd.com/papers/IJTRD7787.pdf

Siddiqui, M. A., Mishra, M. K., Tiwari, P. (2017). Impact of Demonetisation in India. International Journal of Advance Scientific Research and Engineering Trends, 2(1), 14-18.

Sławiński, A. (2011). Polityka pieniężna. Warszawa: C. H. Beck.

The Economist. (2016). The Dire Consequences of India's Demonetisation Initiative. The Economist, December 3. https://www.economist.com/news/finance-and-economics/21711035-withdrawing-86-value-cash-circulation-india-was-bad-idea-badly

Vijaya Kumar, P. (2016a). RBI Instructions to Banks Notification. RBI Notifications https://rbi.org.in/Scripts/NotificationUser.aspx?Id=10684\&Mode $=0$

Vijaya Kumar, P. (2016b). Revisions for Farmers/Traders registered with APMC/Mandis. RBI Notifications. https://www.rbi.org.in/Scripts/NotificationUser.aspx?Id=10730\&Mode $=0$

Vijaya Kumar, P. (2016c). Withdrawal of Legal Tender Character of existing ₹ 500/- and ₹ 1000/- Bank Notes - Applicability of the Scheme to DCCBs. RBI Notifications https://rbidocs.rbi.org.in/rdocs/notification/PDFs/130NTA11A67017CE54B49A788AFDC1599277D.PDF

White, L., \& Rajagopalan, S. (2016). The Indian Government's \$100 Billion Heist. Foundation for Economic Education, December 3. https://fee.org/articles/the-indian-governments-100-billion-heist/

Worstall, T. (2016). Absolutely True - Demonetization Will Boost India's GDP - But How True Is It? Forbes, December 4. https://www.forbes.com/forbes/welcome/?toURL=https://www.forbes.com/sites/timworstall/2016/12/04/absolutely-true-demonetisation-will-boost-indias-gdp-but-howtrue-is-it/\&refURL=https://www.google.com/\&referrer=https://www.google.com/

Dynamic Econometric Models 19 (2019) 41-56 